\title{
The semantic-episodic distinction and the history of long-term memory typologies
}

\author{
DOUGLAS J. HERRMANN \\ Hamilton College, Clinton, New York 13323
}

\begin{abstract}
The field of human memory contains many typologies that distinguish among various types of memory (Ladd, 1894). Once in a while, there is a typology that pertains to the entire memory system. Such a typology requires extra consideration because of its potential impact on research and theory. The semantic-episodic distinction (Tulving, 1972) is such a typology. The present article examined this distinction and its implications through a historical study of predecessors to the distinction in Western thought. The results showed that from Aristotle up to Tulving's statement of the distinction in 1972, there have been many scholars who have proposed distinctions that are similar to the semantic-episodic one. Additionally, the review indicated that instead of a dichotomy (like the semantic-episodic distinction), classification of long-term memory phenomena requires a trichotomy: semantic memory, episodic memory, and skill memory.
\end{abstract}

In 1972, Tulving proposed that long-term memory is of two types, semantic and episodic. "Semantic memory is the memory necessary for the use of language. It is a mental thesaurus, organized knowledge a person possesses about words and other verbal symbols, their meaning and referents, about relations among them, about rules, formulas, and algorithms for the manipulations of these symbols, concepts, and relations" (Tulving, 1972, p. 386). "Episodic memory receives and stores information about temporally dated episodes or events, and temporal-spatial relations among these events" (p. 385). Episodic memories, Tulving explained, have autobiographical content. Semantic memories have cognitive content; that is, they are not concerned with the conditions of acquisition (see also Tulving, 1976a, 1976b).

Since Tulving advanced the semantic-episodic distinction, many have used it to facilitate exposition of a study whose main purpose was unrelated to the distinction, to develop a model of memory consistent with the distinction, or to support the distinction (Nelson \& Brown, 1979; Schacter \& Tulving, in press). Alternatively, several psychologists have claimed that the distinction has no psychological reality (e.g., McKoon, Dell, \& Ratcliff, Note 1). Although the distinction has evoked considerable interest, the implications of the distinction have yet to be fully worked out. In order to elucidate the distinction's implications, the present article examined the history of memory typologies to determine whether any previous typologies resembled the semantic-episodic distinction and, if so, what was the nature of such precedents.

For valuable help on various aspects of this article, I thank Brian Ackerman, Roger Chaffin, Mary Crawford, Nancy Ernst, Debbie Leder, Fred Masterson, John McLaughlin, Billie Nelson, Libby Potter, Dan Schacter, Jonathan Schooler, and Endel Tulving. Requests for reprints should be sent to Douglas J. Herrmann, Department of Psychology, Hamilton College, Clinton, New York 13323.

\section{HISTORY OF TYPOLOGIES CONSISTENT WITH THE SEMANTIC-EPISODIC DISTINCTION}

Tulving (1972) indicated in his initial statement of the distinction that it had precedents in psychology and philosophy, but he chose not to enumerate them at that time. The first examination of precedents was made by Hintzman (1978, p. 367-368), who identified eight. More recently, Schacter and Tulving (in press) identified six precedents (four of which were noted by Hintzman). The present article extends the list of precedents developed by these investigators.

In order for a memory typology to be classified as a precedent for the semantic-episodic distinction, it had to include a type concerned with knowledge and/or skills and a type concerned with episodes (events localized in time and space). A typology did not have to be a dichotomy to be judged as consistent with the semanticepisodic distinction.

Precedents ${ }^{1}$ for the distinction, identified here and previously by Hintzman (1978) and Schacter and Tulving (in press), are listed in Table 1. (Labels provided in the table for the types of typologies were either the terms explicitly used by a scholar to refer to his or her types, or terms taken from a scholar's work by me when a scholar did not explicitly provide labels.) With few exceptions, these precedents involved a very brief description of their respective typologies (sometimes in just a few sentences); rarely has a precedent involved a passage as long or as detailed as Tulving's (1972) chapter (exceptions include Locke, 1971; Malcolm, 1963; Reiff \& Scheerer, 1959). It is impossible in an article of this length to provide relevant quotations for each precedent or to discuss each precedent. Nevertheless, to give an idea of the kind of typologies that anticipated in various ways the semantic-episodic distinction, some illustrative passages will be quoted and/or discussed below. For those readers who would like to 
Table 1

Long-Term Memory Classification Schemes Compatible With the Semantic-Episodic Distinction

\begin{tabular}{|c|c|c|}
\hline Author(s) & Semantic-Memory Term & Episodic-Memory Term \\
\hline \multicolumn{3}{|c|}{ Philosophy } \\
\hline Aristotle (c. $300 \mathrm{BC}$ ) & Affection of Conception & Affection of Perception \\
\hline Augustine (c. 410$)$ & Of Things Learned or Intuited, and Principles & Images of Things Perceived and of Feeling \\
\hline Aquinas (c. 1260) & Thoughts & Fixed in the Past \\
\hline Abercrombie (1833) & Natural or Philosophical Association & Local or Incidental Association \\
\hline Brown (1858) & Conception & Memory of Temporal Relations \\
\hline Bain (1875) & Knowledge & Memory of Experiences \\
\hline Bergson $(1912) * \dagger$ & Habit Memory & True Memory \\
\hline Russell (1912) & Knowledge by Description & Knowledge by Acquaintance \\
\hline Broad (1925) & Nonperceptual Memory & Perceptual Memory \\
\hline Ryle (1949) & Something Learned & Episode \\
\hline Ayer $(1956) *$ & Habit Memory & Event Memory \\
\hline Malcolm (1963) & Factual Memory & Perceptual Memory \\
\hline Locke $(1971)^{*}$ & Factual Memory & Personal Memory \\
\hline Langer (1972) & Factual, Inductive, and Object Memory & Childhood and Biographical Memory \\
\hline \multicolumn{3}{|c|}{ Psychology } \\
\hline Steele (1889) & Logical Memory & Circumstantial Memory \\
\hline James $(1890) \dagger$ & Knowledge & Memory of One's Past \\
\hline Baker (1896) & Philosophic Memory & Circumstantial Memory \\
\hline Wundt $(1896)$ & Cognition & Recognition \\
\hline Angell (1906) & Habit Memory & True Memory \\
\hline McDougall (1923) & Memory in the Wide Sense & Memory in the Narrow Sense \\
\hline Bentley (1925) & Memory from Learning & Memory of the Past \\
\hline Carr (1925) & Conception & Personal Experiences \\
\hline Boring, Langfeld, \& Weld (1935) & Memory for Experience and Habits & Memory Images \\
\hline Koffka (1935) & Skills & Memory of the Past \\
\hline Reiff \& Scheerer (1959)*† & Memoria & Remembrances \\
\hline Bruner (1969) & Memory Without Record & Memory With Record \\
\hline Herrmann (1972) & General Language Store & Separate Event Long-Term Store \\
\hline Piaget \& Inhelder (1973)*† & Memory in the Wide Sense & Memory in the Narrow Sense \\
\hline \multicolumn{3}{|c|}{ Psychiatry } \\
\hline Schactel $(1947)^{*} \dagger$ & Practical Knowledge & Autobiographical Knowledge \\
\hline \multicolumn{3}{|c|}{ Neurology } \\
\hline Clarparede (1911) & Marginal Memory & Egocentric Memory \\
\hline Nielsen $(1958) \dagger$ & Categorical & Temporal \\
\hline Pribram (1969) & Specific & Contextual \\
\hline Luria (1976) & Habit Memory & True Memory \\
\hline Penfield (1975)* & Concepts & Experimental Record \\
\hline
\end{tabular}

*Cited by Hintzman (1978) †Cited by Schacter and Tulving (in press).

examine the original passages for any and all of the precedents, the relevant page or chapter numbers are given. Following Hintzman (1978), the organization of the discussion below and the table is by the discipline within which typologies originated.

\section{Philosophy}

The earliest statement of a typology similar to the semantic-episodic distinction that I found was that of Aristotle (c. $300 \mathrm{BC} / 1931$ ). In "De Memoria et Reminiscenita" of De Anima, Aristotle pointed out that "whenever one exercises the faculty of remembering, he must say within himself, 'I formerly heard (or otherwise perceived) this,' or 'I formerly had this thought' .... Memory is, therefore, neither Perception nor Conception, but a state of affection of one of these conditioned by a lapse of time" (p. 449b).

After Aristotle, the semantic-episodic dark ages set in. To the best of my knowledge, no one dealt with memory typologies until Augustine (334-430 AD). In Confessions and Enchirdion (Augustine, 1955), he noted one type of memory in which "I recall what, when, or where I did a thing or how I felt when I did them" (p. 209). In addition, he identified memory types in which one remembers "all that one has learned of the liberal sciences" (p. 210), that "which we intuit within ourselves without images" (p. 212), and the "principles and unnumbered laws of numbers and dimensions" (p. 212). Much later, in Summa Theologiae, Thomas Aquinas (1260/1964) distinguished between "memory as being in the field of intellect" and "a sense memory... which attends to particulars" fixed "in time" (p. 169).

In the 19th century, Alexander Bain, in The Emotions and the Will (Bain, 1875), devoted separate sections to knowledge and memory, wherein knowledge consists of sensations and perceptions that have been related according to the principles of logic (pp. 567-574), and 
memory consists of a "continuous chain" of experiences (p. 532-535). In the 20th century, some very detailed approaches to memory typology have been advanced. For example, Malcolm (1963) examined in depth the differences between factual memory, which retains propositions or facts, and a perceptual memory, which retains "events, places, or things." More recently, David Locke (1971) proposed a trichotomous typology (Chapter 4) that consists of a factual memory (Chapter 5), defined in the same way Malcolm defined it, a practical memory, concerned with knowing how to do something (Chapter 6), and a personal memory that deals with "people, places, things, events, situationsthat we have personally experienced" (Chapter 7).

\section{Psychology}

The semantic-episodic distinction is not the first typology of its kind to be proposed in psychology; indeed, many psychologists have been concerned with this issue. William James defined memory as pertaining to facts or events. Moreover, he devoted one chapter of his Principles of Psychology (James, 1890) to factual knowledge (Chapter 28) and another to memory of one's past (Chapter 16). Shortly thereafter, Wilhelm Wundt, in his Lectures on Human and Animal Psychology (Wundt, 1896), distinguished between memory as used in cognition and memory as used in recognition. "In the former the impression is assimilated by numerous previous impressions of the same character; in the latter it is associated with a single or with a strictly limited number of past impressions, the terms of the association frequently arranging themselves in a temporal series" (Wundt, 1896, p. 347).

A few decades later, Wilhelm Stern (1938) proposed that memory representation differs between knowledge and remembrance. Stern noted that "the personal significance of verbal, geographical, literary, technical, or other knowledge is not dependent on when and how it was acquired; it is important only that it is on tap when required and that its availability for future undertakings may be counted on. But the personal significance of remembrance depends upon the ability of the consciousness to identify the primary process of the original experience and thereby to relive its past in the present" (p. 218).

\section{Psychiatry}

Schactel (1947) proposed that memory was practical (based on general knowledge) or autobiographical (p. 5). I know of no other precedent to the semanticepisodic distinction in this field.

\section{Neurology}

The first proposal that different neurological systems underlie long-term memory phenomena was made by Edward Claparede (1911/1951). Based on observation of amnesiacs, he discerned that patients could recall "passive associations or idea-reflexes" (called marginal memories) while they could also have great difficulty recalling events from their own pasts (called egocentric memories). This distinction was extended later by Nielson (1958), who differentiated between temporal amnesia, involving a loss of personal experiences, and categorical amnesia, involving a loss of acquired facts (Crovitz, Note 2).

\section{DISCUSSION}

It is clear that many scholars have thought about memory typologies that resemble the semantic-episodic distinction. Of course, the nature of this resemblance is different for each precedent. As Table 1 shows, each emphasizes different aspects of what Tulving has called semantic memory (e.g., principles, knowledge, habit, facts, philosophy, practicalities) and episodic memory (e.g., images, experience, events, percepts, circumstances, autobiography). Although recent discussion about the distinction has touched on some of these aspects, it has yet to attend to others, presumably because most of the precedents for the distinction have been unknown. Thus, the present historical review makes apparent additional aspects of the distinction, aspects that may enhance understanding and evaluation of the distinction.

Besides the differences among the precedents, there are many points of agreement among them. However, it is particularly important that the agreement is less in the semantic types than in the episodic types. Semantic types deal with factual memory, skill memory, or both; in contrast, episodic types deal essentially with episodes. Thus, instead of a dichotomy, the present review of precedents for the semantic-episodic distinction indicates that a typology of long-term memory is best fit into trichotomy: semantic memory, episodic memory, and skill memory (see Locke, 1971 ; Schacter \& Tulving, in press).

\section{REFERENCE NOTES}

1. McKoon, G., Dell, G., \& Ratcliff, R. Priming in item recognition and the distinction between episodic and semantic memories. Unpublished manuscript, Yale University, 1981.

2. Crovitz, H. F. One distinction underlying amnesias. Unpublished manuscript, Durham, North Carolina, 1977.

\section{REFERENCES}

Аве rсомвie, J. Inquiries concerning the intellectual powers and the investigation of truth. New York: Collins \& Brothers, 1833.

Angell, J. R. Psychology. New York: Holt, 1906.

Aristotle. De anima (J. A. Smith, trans.). In W. D. Ross (Ed.), The works of Aristotle (Vol. 3). Oxford: Clarendon Press, 1931. (Originally published, c. 300 BC.)

Augustine. [Confessions and enchiridion] (A. C. Outler, Ed. and trans.). Philadelphia: Westminister Press, 1955. (Originally published, c. 410.)

AYER, A. J. The problem of knowledge. London: Macmillan, 1956.

BAIN, A. The emotions and the will. London: Longmans, Green, 1875.

BAKER, J. H. Elementary psychology. New York: Maynard, Merrill, 1896.

Bentley, M. The field of psychology. New York: Appleton, 1925.

Bergson, H. Matter and memory. New York: Macmillan, 1912.

Boring, E. G., Langfield, H. S., \& Weld, H. P. Psychology. New York: Wiley, 1935.

BroAD, C. D. The mind and its place in nature. London: Routledge \& Kegan Paul, 1925.

Brown, T. Lectures on the philosophy of the human mind. London: William Tegg, 1858. 
Bruner, J. S. Modalities of memory. In G. A. Talland \& N. C. Waugh (Eds.), The pathology of memory, London: Academic Press, 1969.

Carr, H. A. Psychology. New York: Longmans, Green, 1925.

Claparede, E. Recognition and "me-ness." In D. Rapaport (Ed.), Organization and pathology of thought. New York: Columbia University Press, 1951. (Originally published, 1911.)

HerrmanN, D. J. The effects of organization in long-term memory on recognition latency. Unpublished doctoral dissertation, University of Delaware, 1972.

Hintzman, D. L. The psychology of learning and memory. San Francisco: Freeman, 1978.

JAmEs, W. The principles of psychology. New York: Dover, 1890.

KoffKA, K. Principles of Gestalt psychology. New York: Harcourt, 1935.

LADD, G. T. Psychology descriptive and explanatory. New York: Scribner, 1894.

Langer, S. Mind: An essay on feeling (Vol. 2). Baltimore, Md: Johns Hopkins University Press, 1972.

Locke, D. Memory. Garden City, N.Y: Doubleday, 1971.

LURIA, A. R. The neuropsychology of memory. Washington, D.C: Winston, 1976.

Malcolm, N. A definition of factual memory. In N. Malcolm (Ed.), Knowledge and certainty: Essays and lectures. Englewood Cliffs, N.J: Prentice Hall, 1963.

McDougall, W. Outline of psychology. New York: Scribner, 1923.

Nelson, K., \& Brown, A. L. The semantic-episodic memory distinction in memory development. In P. A. Ornstein (Ed.), Memory development in children. Hillsdale, N.J: Erlbaum, 1979.

Nielsen, J. M. Memory and amnesia. Los Angeles: San Lucas Press, 1958.

Penfield, W. The permanent record of the stream of consciousness. Acta Psychologica, 1955, 11, 47-69.

Penfield, W. The mystery of the mind. Princeton, N.J: Princeton University Press, 1975.

Pinget, J., \& Inhelder, B. [Memory and intelligence] (A. J. Pomerans, trans.). New York: Basic Books, 1973.

Pribram, K. H. The amnestic syndromes: Disturbances in cod- ing. In A. Talland \& N. C. Waugh (Eds.), The pathology of memory. New York: Academic Press, 1969.

Reiff, R., \& Scheerer, M. Memory and hypnotic age regression. New York: International Universities Press, 1959.

Russell, B. The problems of philosophy. London: Oxford, 1912.

Russell, B. The analysis of mind. New York: Macmillan, 1921. RYLE, G. The concept of mind. London: Hutchinson, 1949.

Schactel, E. On memory and childhood amnesia. Psychiatry, 1947, 10, 1-26.

Schacter, D. L., \& Tulving, E. Memory, amnesia, and the episodic/semantic distinction. In R. L. Isaacson \& N. S. Spear (Eds.), Expression of knowledge. New York: Plenum, in press.

Steele, G. M. Rudimentary psychology. Boston: Leach, Shewell, \& Sanborn, 1889.

STERN, W. General psychology from a personalistic standpoint. New York: Macmillan, 1938.

Thomas Aquinas. Summa theologiae (Blackfriars edition). New York: McGraw-Hill, 1964. (Originally published, c. 1260.)

Tulving, E. Episodic and semantic memory. In E. Tulving \& W. Donaldson (Eds.), Organization and memory. London: Academic Press, 1972.

Tulving, E. Ecphoric processes in recall and recognition. In J. Brown (Ed.), Recall and recognition. London: Wiley, 1976. (a)

Tulving, E. The role of semantic memory in storage and retrieval of episodic information. In S. Ehrlich \& E. Tulving (Eds.), La memoire semantique, Bulletin de Psychologie, 1976, Special annual, 19-25.

WUNDT, W. Lectures on human and animal psychology. London: Swan Sonnenschein, 189.

\section{NOTE}

1. Although Luria (1973), Penfield (1955, 1975), and Piaget and Inhelder (1973) published their ideas about memory types after Tulving's (1972) seminal chapter, they are included among the bona fide precedents since their ideas were developed independently of Tulving.

(Received for publication August 20, 1982.) 